\title{
Diversity and cellulolytic activity of culturable bacteria isolated from the gut of higher termites (Odontotermes sp.) in eastern Thailand
}

\author{
PARIMA BOONTANOM, AIYA CHANTARASIRI \\ Faculty of Science, Energy and Environment, King Mongkut's University of Technology North Bangkok. \\ Rayong Campus, Rayong 21120, Thailand. Tel./fax.: +66-38-627000 ext.5446, `email: aiya.c@ sciee.kmutnb.ac.th \\ Manuscript received: 10 June 2021. Revision accepted: 21 July 2021.
}

\begin{abstract}
Boontanom P, Chantarasiri A. 2021. Diversity and cellulolytic activity of culturable bacteria isolated from the gut of higher termites (Odontotermes sp.) in eastern Thailand. Biodiversitas 22: 3349-3357. Cellulolytic bacteria are vital symbionts associated with the gut of all higher termites. Odontotermes termites are a higher termite widely found in Thailand. However, information concerning the diversity of cellulolytic bacteria in this termite gut remains inadequate. The aim of this study is to isolate and identify the culturable cellulolytic bacteria from the Odontotermes gut collected from eastern Thailand. The crude cellulases produced from the most active cellulolytic bacterium were further characterized. Thirty-two cellulolytic bacteria were isolated and subsequently classified by PCRRFLP of the $16 \mathrm{~S}$ rRNA gene. A total of 10 different RFLP patterns were obtained belonging to five bacterial genera, namely Acinetobacter, Bacillus, Citrobacter, Paenibacillus, and Serratia. The B. cereus strain TWV503 was considered to be the most active cellulolytic bacterium based on the CMC agar method. B. cereus strain TWV503 showed CMCase activity at $2.190 \pm 0.063 \mathrm{U} / \mathrm{mL}$ of CMCase and $0.276 \pm 0.031 \mathrm{U} / \mathrm{mL}$ of FPase. The optimum temperature and $\mathrm{pH}$ for $\mathrm{CMCase}$ activity were $50^{\circ} \mathrm{C}$ and the neutral $\mathrm{pH}$ ranging from 7.0 to 8.0 , respectively. CMCase activity remained stable at up to $70^{\circ} \mathrm{C}$ and neutral $\mathrm{pH}$ ranging from 7.0 to 8.0 for 24 hours of incubation. This study revealed novel information related to cellulolytic bacteria isolated from the gut of Odontotermes termites collected from Thailand.
\end{abstract}

Keywords: Bacillus cereus, cellulase, cellulolytic bacteria, Odontotermes, termite

\section{INTRODUCTION}

Termites are small eusocial insects at the taxonomic rank of Order Isoptera, Phylum Arthropoda that are highly abundant in tropical and subtropical regions (Brune 2014). They are commonly classified into two major groups involving lower and higher termites. The lower termites are phylogenetically basal and comprise six families including Mastotermitidae, Termopsidae, Hodotermitidae, Kalotermitidae, Serritermitidae, and Rhinotermitidae (Hongoh 2011; Korb 2018). The higher termites are phylogenetically apical and comprise only the family Termitidae (Hongoh 2011; Korb 2018). Almost all families of lower termites are wood feeders, except for the members of family Hodotermitidae, which are dead grass feeders (Hongoh 2011). The higher termites forage a wide variety of lignocellulosic biomass and materials such as wood, dry grass, herbivore dung, lichen, plant litter, organic matter, and soil (Hongoh 2011; Brune 2014; Mikaelyan et al. 2015). Therefore, they play a vital role in general plant decomposition, carbon cycling of organic matters, and recycling nutrients of ecosystems (König et al. 2013; Otani et al. 2014).

Microbial diversity associated with termite gut has been widely studied by both culture-dependent and independent methods (Manjula et al. 2016). These microbes show a mutualistic beneficial relationship with termites and typically convert complex polysaccharides of lignocellulosic biomass into simpler saccharides by hydrolytic enzymes comprising cellulases, cellubiases, hemicellulases, glucosidases, and gluconases (Maurice and Erdei 2018). Lower termites predominantly harbor archaea, bacteria, and flagellated protists within their digestive tracts, whereas higher termites are mainly associated with bacteria (Brune 2014; Peterson and Scharf 2016). However, gut microbiota varies markedly among termite species (Maurice and Erdei 2018).

Previous studies reported that the total number of bacteria in the termite gut is within the range of $10^{7}$ to $10^{11}$ per milliliter (König et al. 2013), which mainly belong to Phyla Actinobacteria, Bacteroidetes, Firmicutes, and Proteobacteria (Manjula et al. 2016). Many strains of bacterial symbionts are considered cellulolytic bacteria and have been isolated (Ferbiyanto et al. 2015; Sharma et al. 2015; Sreena et al. 2015). Cellulolytic bacteria can hydrolyze the $\beta-1,4$ glycosidic linkage of cellulose polymers producing sugar derivatives by their cellulolytic enzymes, generally called cellulases (Chantarasiri 2015; 2020). Cellulases are grouped into the glycosyl hydrolase (GH) family comprising endoglucanases (E.C. 3.2.1.4), exoglucanases (E.C. 3.2.1.91, E.C. 3.2.1.176), and $\beta$ glucosidases (E.C. 3.2.1.21) (Juturu and Wu 2014; Obeng et al. 2017). Today, cellulases comprise up to $8 \%$ of the worldwide industrial enzyme demand (Shweta 2014). They have shown their potential applications over decades in various industrial processes such as textile, food and feed, paper and pulp, biorefinery, and agricultural industries (Menendez et al. 2015). Therefore, the study of cellulolytic 
bacteria in termite gut is challenging for the screening of effective cellulases.

Odontotermes is a genus of fungus-growing termites in the family Termitidae (higher termites) that reside throughout the tropical and subtropical regions of Africa and Asia (Chiu et al. 2018). Odontotermes termites are agricultural pests that attack crops and trees, and are commonly found in Thailand (Wititsiri 2011; Chiu et al. 2018). Information about cellulolytic bacteria isolated from the Odontotermes termites is scarce. Therefore, this study aimed to isolate and screen cellulolytic bacteria from the gut of Odontotermes termites in the eastern region of Thailand. The polymerase chain reaction-restriction fragment length polymorphism (PCR-RFLP) and nucleotide sequencing analysis of $16 \mathrm{~S}$ rRNA genes were used to describe the diversity of isolated cellulolytic bacteria.

\section{MATERIALS AND METHODS}

\section{Study area and sampling of termites}

The study area of this study includes three provinces located in the eastern region of Thailand comprising Rayong Province $\left(12^{\circ} 49^{\prime} \mathrm{N}, 101^{\circ} 13^{\prime} \mathrm{E}\right)$, Chachoengsao Province $\left(13^{\circ} 37^{\prime} \mathrm{N}, 101^{\circ} 18^{\prime} \mathrm{E}\right)$ and Prachin Buri Province $\left(14^{\circ} 6^{\prime} \mathrm{N}, 101^{\circ} 19^{\prime} \mathrm{E}\right)$. Odontotermes termites were collected randomly from the groves and grasslands of the study area. The collected termites were morphologically identified based on their unique heads and mandibles. Higher termites in the genus Odontotermes have symmetrical mandibles curved at the tips, with minute or nonexistent teeth at the right mandible. The left mandible has one or two teeth or a serrated cutting edge. Fifty termites were collected during the winter season in January 2017 and kept in sterilized plastic bags at $4^{\circ} \mathrm{C}$. Bacterial isolation was performed within 48 hours of collection.

\section{Procedures}

Isolation of bacteria from termite gut samples

The isolation of bacteria from collected termites was conducted according to Sharma et al. (2015) with minor modifications. Termite samples were surface sterilized by dipping into $70 \%(\mathrm{v} / \mathrm{v})$ ethanol for 10 seconds and washed in sterilized $0.85 \%(\mathrm{w} / \mathrm{v}) \mathrm{NaCl}$ solution for 30 seconds. Each entire gut of a sterilized termite was picked out by an inoculum needle under an SMZ445 stereomicroscope (Nikon, Japan). The dissection procedures were performed under aseptic conditions in a modified NU-440 biosafety cabinet (NuAire, USA). The termite gut was transferred to $1 \mathrm{~mL}$ of Tryptone soy broth (TSB) (HiMedia, India) and incubated at $30^{\circ} \mathrm{C}$ for 24 hours to enrich the culturable bacterial symbionts. The enriched cultures were serially diluted with sterilized $0.85 \%$ (w/v) $\mathrm{NaCl}$ solution to obtain 1:10,000 dilutions and spread plated on Tryptone soya agar (TSA) (HiMedia, India). All culture plates were incubated at $30^{\circ} \mathrm{C}$ for 24 hours. The bacterial isolates were selected based on the morphology of colony, and the colony was subsequently purified by streak plated on TSA.

\section{Screening of cellulolytic bacteria}

The bacterial isolates were cultured in $1 \mathrm{~mL}$ of TSB at $30^{\circ} \mathrm{C}$ for 24 hours. One drop $(5 \mu \mathrm{L})$ of each isolated bacterium was placed on CMC agar for screening of cellulolytic bacteria. The CMC agar contained carboxymethyl cellulose (CMC) as a sole carbon source for bacterial growth which was previously described by Chantarasiri (2015). All culture plates were incubated at $30^{\circ} \mathrm{C}$ for 48 hours and then flooded with iodine solution for 15 minutes. The iodine solution comprised $0.33(\mathrm{w} / \mathrm{v}) \mathrm{I}_{2}$ and $0.67 \%(\mathrm{w} / \mathrm{v}) \mathrm{KI}$ as described by Chantarasiri et al. (2015). The cellulolytic bacteria produce the clear zones around the colonies on CMC agar by the hydrolysis mechanisms of their producing cellulases. These clear zones were visualized after staining by iodine solution. The hydrolysis capacity (HC) value of cellulolytic bacteria was calculated from the ratio between the diameter of the clear zone and the diameter of the bacterial colony (Chantarasiri 2014). All the experiments were performed in triplicates.

Polymerase chain reaction-restriction fragment length polymorphism (PCR-RFLP) analysis of $16 \mathrm{~S}$ rRNA genes

The genomic DNA of each cellulolytic bacterium was extracted using a Genomic DNA isolation kit (Bio-Helix, Taiwan). Polymerase chain reaction (PCR) amplification of the 16S rRNA genes was carried out using an OnePCR reaction mixture (Bio-Helix, Taiwan) with a universal $27 \mathrm{~F}$ primer (5'-AGAGTTTGATCMTGGCTCAG-3') and a universal 1492R primer (5'-TACGGYTACCTTGTTACG ACTT-3') for 35 amplification cycles. The amplification parameters were conducted according to Boontanom and Chantarasiri (2020) in a Master cycler Nexus Gradient thermal cycler (Eppendorf, Germany), which involved a preheating step at $94^{\circ} \mathrm{C}$ for 4 minutes, a denaturation step at $94^{\circ} \mathrm{C}$ for 40 seconds, an annealing step at $55^{\circ} \mathrm{C}$ for 1 minute, an extension step at $72^{\circ} \mathrm{C}$ for 1 minute 10 seconds, and a final extension step at $72^{\circ} \mathrm{C}$ for 10 minutes.

The restriction fragment length polymorphism (RFLP) analysis of the PCR products was performed by two restriction enzymes of $M s p \mathrm{I}$ and $A l u \mathrm{I}$ (New England Biolabs, UK) in a CutSmart buffer (New England Biolabs, UK) following the previous protocol described by Chantarasiri (2020). The PCR products were cleaved with MspI and $A l u \mathrm{I}$ at $37^{\circ} \mathrm{C}$ for 12 hours then the reaction was terminated by heating the reaction mixtures at $80^{\circ} \mathrm{C}$ for 15 minutes. The resulting DNA fragments were electrophoresed on a $3 \%(w / v)$ OmniPur agarose gel (Calbiochem, Germany) and visualized by Novel Juice staining (Bio-Helix, Taiwan) on an MD-25/HD-25 UVtransilluminator (Wealtec, Taiwan). The PCR marker used was OneMark 100 RTU DNA ladder (Bio-Helix, Taiwan).

\section{Nucleotide sequencing and phylogenetic analysis of amplified 16S rRNA genes}

The 16S rRNA genes of each cellulolytic bacterium were PCR amplified according to the aforementioned method. They were preliminary verified on a $1.5 \%(\mathrm{w} / \mathrm{v})$ OmniPur agarose gel and visualized by Novel Juice staining. The $1,500 \mathrm{bp}-\mathrm{PCR}$ products were purified and sequenced by the services of Macrogen Inc. (Korea). The 
sequenced 16S rRNA genes were aligned for similarity analysis by the BLASTn program based on the nucleotide collection (nr/nt) database and a megablast algorithm from the National Center for Biotechnology Information (NCBI). The phylogenetic tree of cellulolytic bacteria was analyzed by SeaView software version 5.0.1 and FigTree software version 1.4 .4 with the neighbor-joining (NJ) method for 100,000 bootstrap replications. All the resulting nucleotide sequences were deposited in the GenBank database of NCBI under the accession numbers MW713798, MW713799, MW713800, MW713801, MW713802, MW713926, MW713927, MW713936, MW713979, and MW713980.

\section{Preparation of the crude cellulases from the most effective cellulolytic bacterium}

The most effective cellulolytic bacterium based on the HC value was $B$. cereus strain TWV503. It was subsequently cultured for preparation of the crude cellulases in a CMC liquid medium (Chantarasiri 2015). The bacterial cultures were shaken under an aeration condition at $150 \mathrm{rpm}$ for 48 hours at $30^{\circ} \mathrm{C}$. Crude cellulases were harvested from the liquid medium as the cell-free supernatant by centrifugation at $4,500 \times \mathrm{g}$ for 30 minutes. The crude enzyme solution was concentrated by $10-\mathrm{kDa}$ Amicon ultra centrifugal filter units (Millipore, Ireland) and kept at $4^{\circ} \mathrm{C}$.

Cellulolytic activity assays of the crude cellulases from the most effective cellulolytic bacterium

The cellulolytic activity assays of the crude cellulases were conducted as previously described study (Chantarasiri et al. 2015). Endoglucanase activity (CMCase activity) was determined by incubating $0.5 \mathrm{~mL}$ of crude cellulases with $0.5 \mathrm{~mL}$ of $2 \%(\mathrm{w} / \mathrm{v}) \mathrm{CMC}$ sodium salt as a substrate in an assay buffer at $50^{\circ} \mathrm{C}$ for 30 minutes. Total cellulase activity (FPase activity) was determined by incubating $0.5 \mathrm{~mL}$ of crude cellulases with $50 \mathrm{mg}$ of grade 1 qualitative filter paper (Whatman, Germany) as a substrate in an assay buffer at $50^{\circ} \mathrm{C}$ for 1 hour. The reducing sugars released from the substrates were spectrophotometrically determined by a standard 3,5-dinitrosalicylic acid (DNS) method at $540 \mathrm{~nm}$. The cellulolytic activity values were calculated by a glucose standard curve. One unit (U) of cellulolytic activity was defined as the amount of enzyme required to release $1 \mu \mathrm{mol}$ of the reducing sugars as glucose equivalent per minute under the assay conditions. The assay buffer used was $50 \mathrm{mM}$ sodium phosphate buffer at $\mathrm{pH} 7.0$ according to the previous study (Chantarasiri 2020). Spectrophotometric analysis was performed using an AccuReader microplate reader (Metertech, Taiwan). All the experiments were performed in triplicates.
Enzymatic characterization of the crude cellulases from the most effective cellulolytic bacterium

The experiment focused on the temperature and $\mathrm{pH}$ values that affected the CMCase activity of the crude cellulase producing from $B$. cereus strain TWV503. The CMCase assay was measured accordingly, as mentioned in the previous experiment. All the experiments were performed in triplicates.

The optimum temperature of the cellulolytic activities was characterized at temperatures ranging from $25^{\circ} \mathrm{C}$ to $80^{\circ} \mathrm{C}$ in an assay buffer. Thermal stability was characterized by pre-incubating the crude cellulases at temperatures ranging from $25^{\circ} \mathrm{C}$ to $80^{\circ} \mathrm{C}$ for 24 hours in an assay buffer, and the relative activity of cellulases was monitored. The assay buffer used was $50 \mathrm{mM}$ sodium phosphate buffer at $\mathrm{pH}$ of 7.0.

The effect of $\mathrm{pH}$ on the cellulolytic activities was characterized in the $\mathrm{pH}$-varied buffers at $50^{\circ} \mathrm{C}$. The optimum $\mathrm{pH}$ of the cellulolytic activities was determined in assay buffers comprising $50 \mathrm{mM}$ citrate buffer $(\mathrm{pH} 4.0$ 6.0), $50 \mathrm{mM}$ sodium phosphate buffer ( $\mathrm{pH}$ 6.0-8.0), $50 \mathrm{mM}$ Tris- $\mathrm{HCl}$ buffer ( $\mathrm{pH} 8.0-9.0$ ), and $50 \mathrm{mM}$ glycine-NaOH buffer ( $\mathrm{pH}$ 9.0-10.0). The $\mathrm{pH}$ stability was measured by pre-incubating the crude cellulases at $50^{\circ} \mathrm{C}$ for 24 hours in the above-mentioned buffers, and the relative activity of cellulases was monitored.

\section{Data analysis}

The statistical analysis was achieved by one-way ANOVA followed by Tukey's test with a 95\% confidence interval using $\mathrm{R}$ software version 4.0.3 ( $\mathrm{R}$ Core Team 2020).

\section{RESULTS AND DISCUSSION}

\section{Isolation and screening of cellulolytic bacteria from the termite gut samples}

Result revealed that 72 bacterial isolates were isolated on TSA medium from the gut of fifty Odontotermes termites under laboratory conditions. Thirty-two bacterial isolates were considered as active cellulolytic bacteria (44.4\% of the isolated bacteria) based on the CMC agar method. These cellulolytic bacteria were obtained from 16 isolates of Rayong Province (named with the isolate codes of TWV and PJE), 3 isolates of Chachoengsao Province (named with the isolate codes of EHK), and 13 isolates of Prachin Buri Province (named with the isolate codes of BEI and IKN). The HC values of the cellulolytic bacteria ranged from $1.07 \pm 0.04$ to $4.44 \pm 0.10$, as shown in Table 1. Isolate TWV503 from a termite gut in Rayong Province showed maximum $\mathrm{HC}$ of $4.44 \pm 0.10$ and was designated as the most effective cellulolytic bacterium in this study. The cellulolytic zone of TWV503 on CMC agar after iodine solution staining is shown in Figure 1. 
Table 1. HC values of thirty-two cellulolytic bacteria isolated from termite gut in three provinces of eastern Thailand.

\begin{tabular}{cccc}
\hline \multirow{2}{*}{ HC value } & \multicolumn{3}{c}{ Bacterial isolates } \\
\cline { 2 - 4 } & Rayong Province & Chachoengsao Province & Prachin Buri Province \\
\hline $1.00-1.99$ & TWV101, TWV102, TWV301, TWV502 & EHK105, EHK401 & IKN501 \\
$2.00-2.99$ & PJE201 & EHK503 & BEI104, BEI203, BEI305, \\
& BEI502, IKN102, IKN201 \\
$3.00-3.99$ & TWV103, TWV202, TWV302, TWV402, TWV404, & BEI102, BEI201, BEI304, \\
$>4.00$ & PJE101, PJE202, PJE401, PJE402, PJE501 & BEI308, BEI402, IKN103 \\
\hline
\end{tabular}

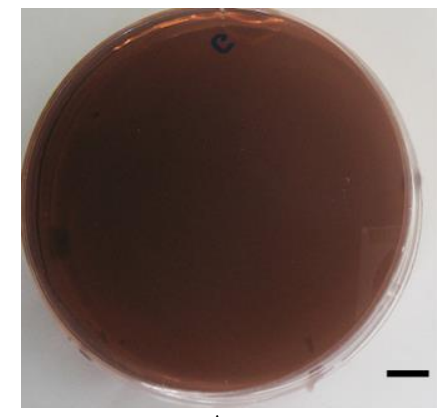

$\mathbf{A}$

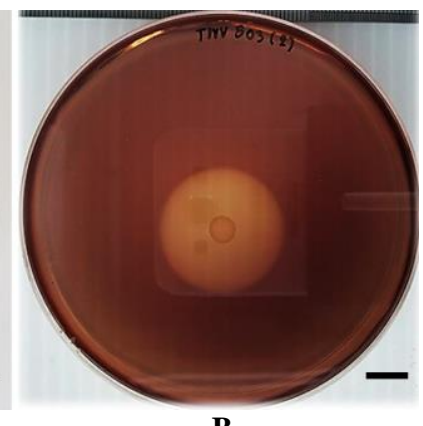

$\mathbf{B}$

Figure 1. The cellulolytic zone around the bacterial colonies on CMC agar after iodine solution staining. A. Non-cellulolytic bacterium as negative control, B. Cellulolytic bacterium isolate TWV503. $\mathrm{Bar}=1 \mathrm{~cm}$

\section{PCR-RFLP analysis of the 16S rRNA genes amplified from the cellulolytic bacteria}

The 16S rRNA genes of the isolated cellulolytic bacteria were amplified by the PCR method, cleaved by the restriction enzymes, and electrophorized on agarose gel. The resulting RFLP profiles electrophorized on agarose gel are shown in Figure 2. Ten different patterns of the RFLP profiles were obtained from 32 isolates of cellulolytic bacteria. The different patterns of the RFLP profiles are summarized in Table 2. All RFLP patterns were definite arrangements and practicable for bacterial categorization.

The RFLP profiles revealed that the cellulolytic bacteria isolated from the termite gut in Rayong Province had the highest biodiversity with 5 different patterns. The RFLPTWV-03, RFLP-PJE-01, and RFLP-BEI-01 patterns were the most commonly found patterns in the RFLP profiles. Interestingly, there were 5 RFLP patterns from different provinces that were closely similar comprising RFLPTWV-03, RFLP-PJE-01, RFLP-EHK-01, RFLP-BEI-01, and RFLP-IKN-01. A pair of patterns RFLP-TWV-01 and RFLP-EHK-02 also showed a similar pattern. The similar RFLP patterns were possibly believed to be the same species of cellulolytic bacteria associated with the gut of Odontotermes termites.

\section{Identification of the cellulolytic bacteria by nucleotide} sequencing and phylogenetic analysis

The genomic DNA was extracted from 10 different bacteria based on the RFLP patterns and amplified by the universal primers, $27 \mathrm{~F}$ and $1492 \mathrm{R}$. The alignment results exhibited that the cellulolytic bacteria from termite gut belonged to 5 genera including Acinetobacter, Bacillus, Citrobacter, Paenibacillus, and Serratia (Table 3). The Acinetobacter, Citrobacter, and Serratia genera were classified in the Phylum Proteobacteria, whereas the Bacillus and Paenibacillus genera were classified in the Phylum Firmicutes.

The cellulolytic bacteria isolated from the termite gut in Rayong Province (RFLP-TWV and PJE-patterns) were closely similar to Acinetobacter baumannii, Bacillus cereus, Citrobacter farmeri, and Serratia marcescens with $99 \%$ identity and $99 \%$ query coverage. The cellulolytic bacteria isolated from termite gut in Chachoengsao Province (RFLP-EHK-patterns) were closely similar to $B$. cereus and Citrobacter sp. with $99 \%$ identity and $99 \%$ query coverage. Lastly, the cellulolytic bacteria isolated from termite gut in Prachin Buri Province (RFLP-BEI and IKN-patterns) were closely similar to $B$. cereus and Paenibacillus polymyxa with $99 \%$ identity and 98-99\% query coverage. All $\mathrm{E}$ values obtained from the alignment were zero. The phylogenetic tree of the isolated cellulolytic bacteria with 100,000 bootstrap replications is shown in Figure 3. There were 6 RFLP patterns that fell into the phylogenetic clade of Firmicutes, such as RFLP-TWV-03, RFLP-PJE-01, RFLP-EHK-01, RFLP-BEI-01, RFLP-INK01 and RFLP-INK-02 with a bootstrap value of 60-100, while the RFLP-TWV-01, RFLP-TWV-02, RFLP-TWV04, and RFLP-EHK-02 were clustered in the phylogenetic clade of Proteobacteria with a bootstrap value of 40-100. The alignment and phylogenetic tree results showed the explicit identification of cellulolytic bacteria isolated from the termite gut. The alignment and phylogenetic tree results confirmed the hypothesized identification of the same RFLP patterns, as mentioned above. The group of RFLP patterns (RFLP-TWV-03, RFLP-PJE-01, RFLP-EHK-01, RFLP-BEI-01, and RFLP-IKN-01) was identified as $B$. cereus, while a pair of RFLP patterns (RFLP-TWV-01 and RFLP-EHK-02) was identified as Citrobacter species. 
Table 2. Different RFLP patterns and numbers of the thirty-two isolated cellulolytic bacteria from termite gut

\begin{tabular}{lcc}
\hline \multicolumn{1}{c}{ RFLP patterns } & Bacterial isolates & $\begin{array}{c}\text { Total number of } \\
\text { bacterial isolate }\end{array}$ \\
\hline RFLP-TWV-01 & TWV101, TWV502 & 2 \\
RFLP-TWV-02 & TWV102 & 1 \\
RFLP-TWV-03 & TWV103, TWV202, TWV302, TWV402, TWV404, TWV503 & 6 \\
RFLP-TWV-04 & TWV301 & 1 \\
RFLP-PJE-01 & PJE101, PJE201, PJE202, PJE401, PJE402, PJE501 & 6 \\
RFLP-EHK-01 & EHK105, EHK503 & 2 \\
RFLP-EHK-02 & EHK401 & 1 \\
RFLP-BEI-01 & BEI102, BEI104, BEI201, BEI203, BEI304, BEI305, BEI308, BEI402, BEI502 & 9 \\
RFLP-IKN-01 & IKN102, IKN103, IKN501 & 3 \\
RFLP-IKN-02 & IKN201 & 1 \\
\hline
\end{tabular}

Table 3. Identity percentage of the $16 \mathrm{~S}$ rRNA gene sequences for the isolated cellulolytic bacteria

\begin{tabular}{llccc}
\hline RFLP patterns & \multicolumn{1}{c}{ Closely related bacteria } & $\begin{array}{c}\text { GenBank } \\
\text { Accession No. } \\
\text { (Database) }\end{array}$ & $\begin{array}{c}\text { GenBank } \\
\text { Identity (\%) }\end{array}$ & $\begin{array}{c}\text { * } \\
\text { Accession No. } \\
\text { (Deposited) }\end{array}$ \\
\hline RFLP-TWV-01 & Citrobacter farmeri strain 33-5 & MN400096.1 & 99.93 & MW713798 \\
RFLP-TWV-02 & Acinetobacter baumannii strain st10 & MF102141.1 & 99.86 & MW713799 \\
RFLP-TWV-03 & Bacillus cereus strain MBL13 & GQ148914.1 & 99.72 & MW713802 \\
RFLP-TWV-04 & Serratia marcescens strain SerEW01 & MK961214.1 & 99.93 & MW713800 \\
RFLP-PJE-01 & Bacillus cereus strain P14 & JN700160.1 & 99.86 & MW713801 \\
RFLP-EHK-01 & Bacillus cereus strain 165PP & KM349191.1 & 99.38 & MW713926 \\
RFLP-EHK-02 & Citrobacter sp. strain XT-15 & KR063546.1 & 99.65 & MW713927 \\
RFLP-BEI-01 & Bacillus cereus strain D21 & KC441762.1 & 99.51 & MW713979 \\
RFLP-IKN-01 & Bacillus cereus strain LXJ77 & MN746190.1 & 99.17 & MW713980 \\
RFLP-IKN-02 & Paenibacillus polymyxa strain KCTC 3627 clone 6 & HE981771.1 & 99.24 & MW713936 \\
\hline N
\end{tabular}

Note: * The identity results were analyzed on March 8, 2021

Remarkably, B. cereus were the predominant bacteria found in the gut of Odontotermes termites in this study. All the resulting nucleotide sequences were deposited in the GenBank database of NCBI under the accession numbers MW713798, MW713799, MW713800, MW713801, MW713802, MW713926, MW713927, MW713936, MW713979, and MW713980.

\section{Cellulolytic activity and enzymatic characterization of the crude cellulases from $B$. cereus strain TWV503}

The bacterium isolate TWV503 was considered the most effective bacteria based on its $\mathrm{HC}$ value from $\mathrm{CMC}$ agar. This bacterium was then designated as B. cereus strain TWV503 according to the alignment and phylogenetic tree results of the $16 \mathrm{~S}$ rRNA gene. The result of cellulolytic activity assays showed that B. cererus strain TWV503 could produce crude cellulases $2.190 \pm 0.063$ $\mathrm{U} / \mathrm{mL}$ of CMCase and $0.276 \pm 0.031 \mathrm{U} / \mathrm{mL}$ of FPase under experimental conditions. It was also noted that $B$. cereus strain TWV503 produced cellulases with satisfactory CMCase performance.

Crude cellulases from B. cereus strain TWV503 were characterized for CMCase activity at different temperatures and $\mathrm{pH}$ values. The optimum temperature and $\mathrm{pH}$ for CMCase activity were a moderate temperature at $50^{\circ} \mathrm{C}$ and a neutral $\mathrm{pH}$ ranging from 7.0 to 8.0 of sodium phosphate buffer $(p<0.01)$. The optimum temperature and $\mathrm{pH}$ for the enzyme are shown in Figures 4.A and 5.A, respectively. The crude cellulases of $B$. cereus strain TWV503 remained stable at up to $70^{\circ} \mathrm{C}$ and $\mathrm{pH}$ range of 7.0 to 8.0 after 24 hours of experimental incubation $(p<0.01)$. Thermal and $\mathrm{pH}$ stability for the enzymes is shown in Figures 4.B and 5.B, respectively. The buffer types barely affected the activity and stability of CMCase at the same $\mathrm{pH}$ value, as shown in Figure 5.

\section{Discussion}

Termites are major lignocellulosic biomass feeding insects that have ecological importance in the global carbon cycle (König et al. 2013). Termites can digest the ingested lignocellulosic biomass not only by their cellulases but also by cellulases from the microbial symbionts in their gut. Higher termites in the family Termitidae mainly harbor cellulolytic bacteria, which show a mutualistic beneficial relationship in their gut. However, few studies in recent decades have reported on cellulolytic bacteria isolated from the higher termites in Thailand. A report of cellulolytic bacteria isolated from the Microcerotermes higher termites collected from Thailand found that the cellulolytic $B$. subtilis isolate M 015 provided the highest endoglucanase activity, whereas B. subtilis isolate M018 showed the highest FPase activity (Taechapoempol et al. 2011). Metagenomic analysis of microbial communities residing in the hindguts of Microcerotermes termites collected from Thailand showed only 2 active clones of cellulase activity closely related to the unidentified uncultured bacteria (Nimchua et al. 2012). 


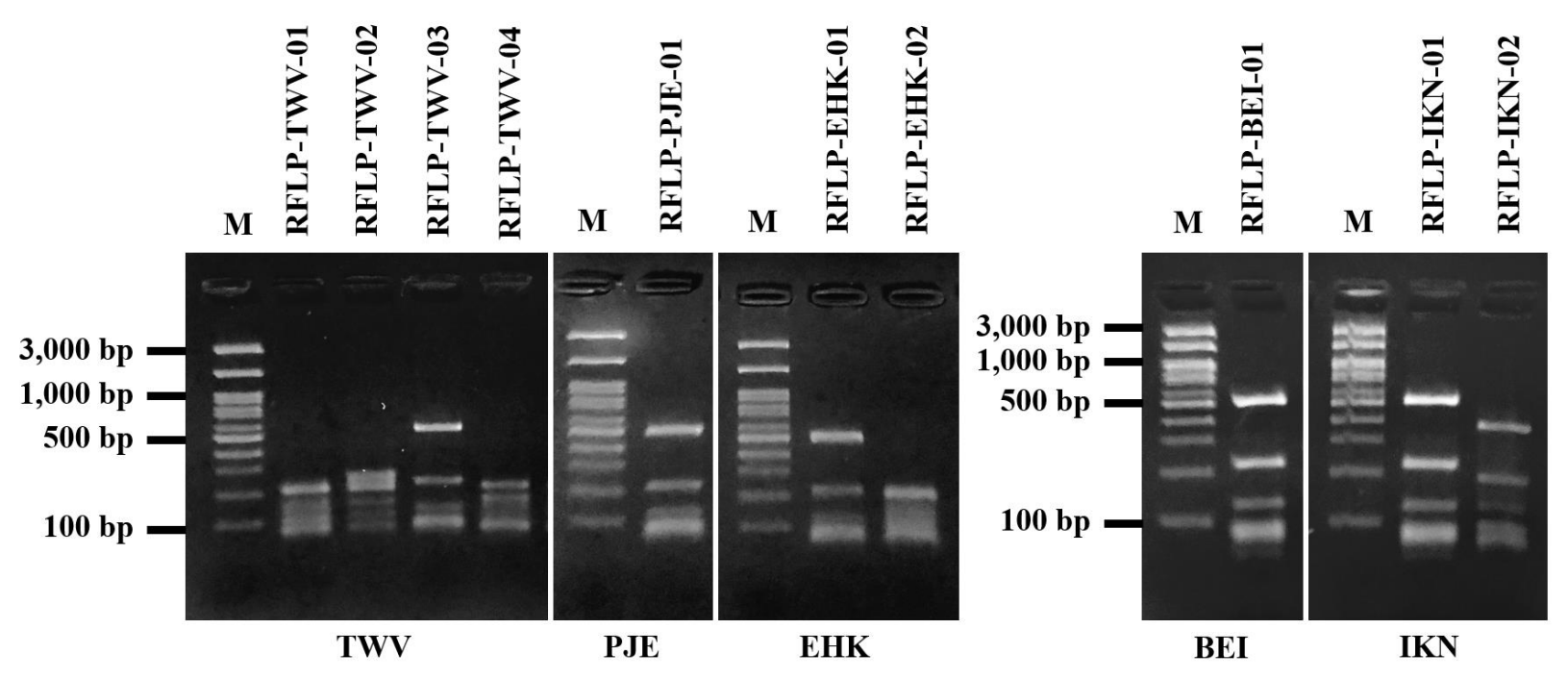

Figure 2. RFLP profiles resulting from the PCR-RFLP analysis of the thirty-two isolated cellulolytic bacteria. M denotes OneMark 100 RTU DNA ladder

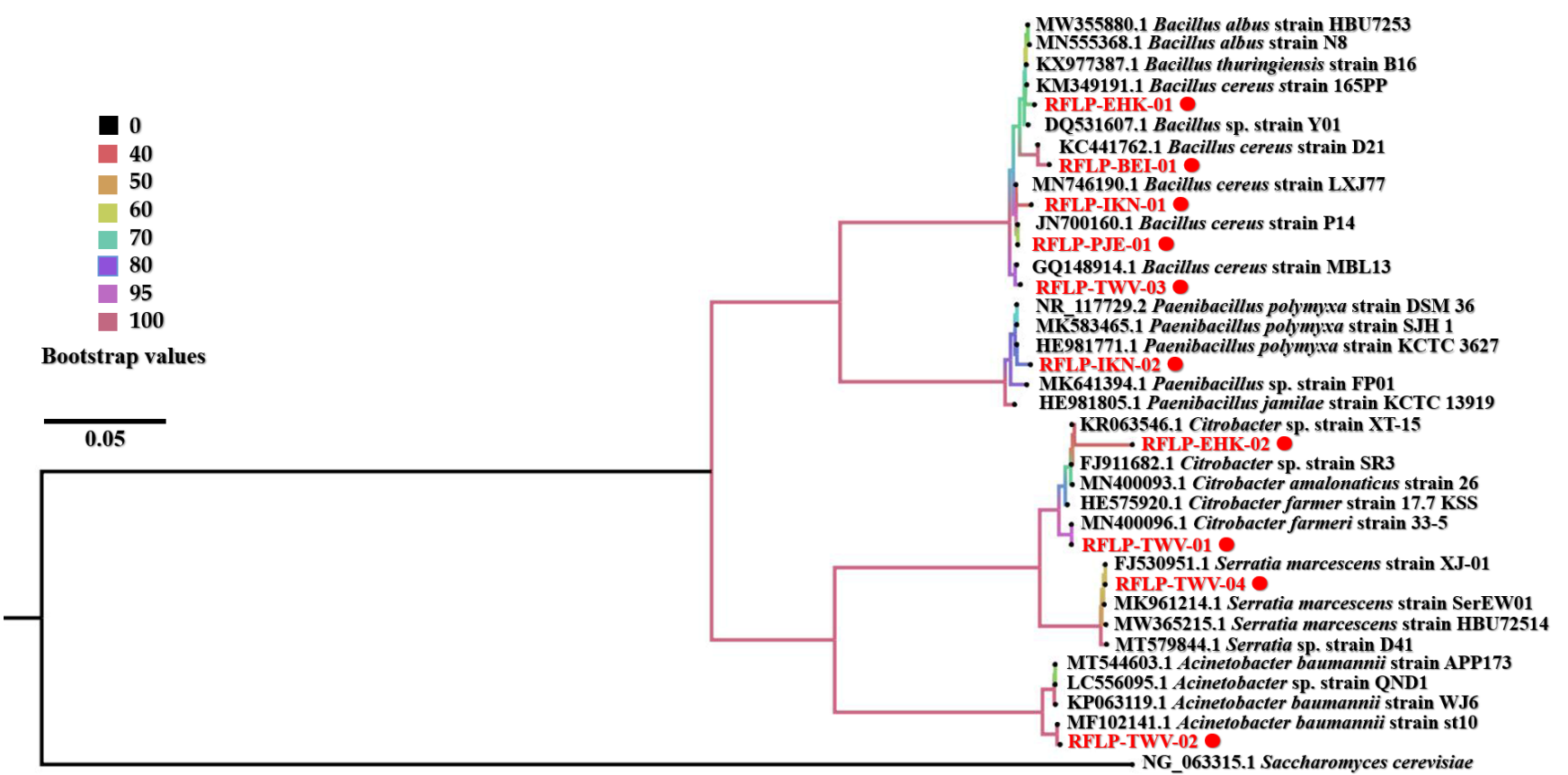

Figure 3. Phylogenetic tree of isolated cellulolytic bacteria using the NJ algorithm with 100,000 bootstrap replications. The phylogenetic tree was generated by SeaView software version 5.0.1 and FigTree software version 1.4.4

This study involved the isolation and screening of the culturable cellulolytic bacteria from the gut of Odontotermes higher termites collected from 3 provinces located in the eastern region of Thailand. Noticeably, information about the gut microbial diversity of the genus Odontotermes remains inadequate (Makonde et al. 2013). Thirty-two cellulolytic bacteria were isolated and subsequently classified by PCR-RFLP analysis. Ten different RFLP patterns were obtained and the representative bacterium from each RFLP pattern was identified. Result exhibited that 6 species of cellulolytic bacteria from 2 phyla were genetically and phylogenetically identified, including $B$. cereus and $P$. polymyxa of the Phylum Firmicutes, and A. baumannii, Citrobacter sp., C. farmeri, and S. marcescens of the Phylum Proteobacteria. According to a previous report on the bacterial diversity in the gut of Odontotermes sp. and O. somaliensis termites, it was found that 7 bacterial phyla represented such as Actinobacteria, Bacteroidetes, Firmicutes, Planctomycetes, Proteobacteria, Spirochaetes, and Synergistetes (Makonde et al. 2013). 

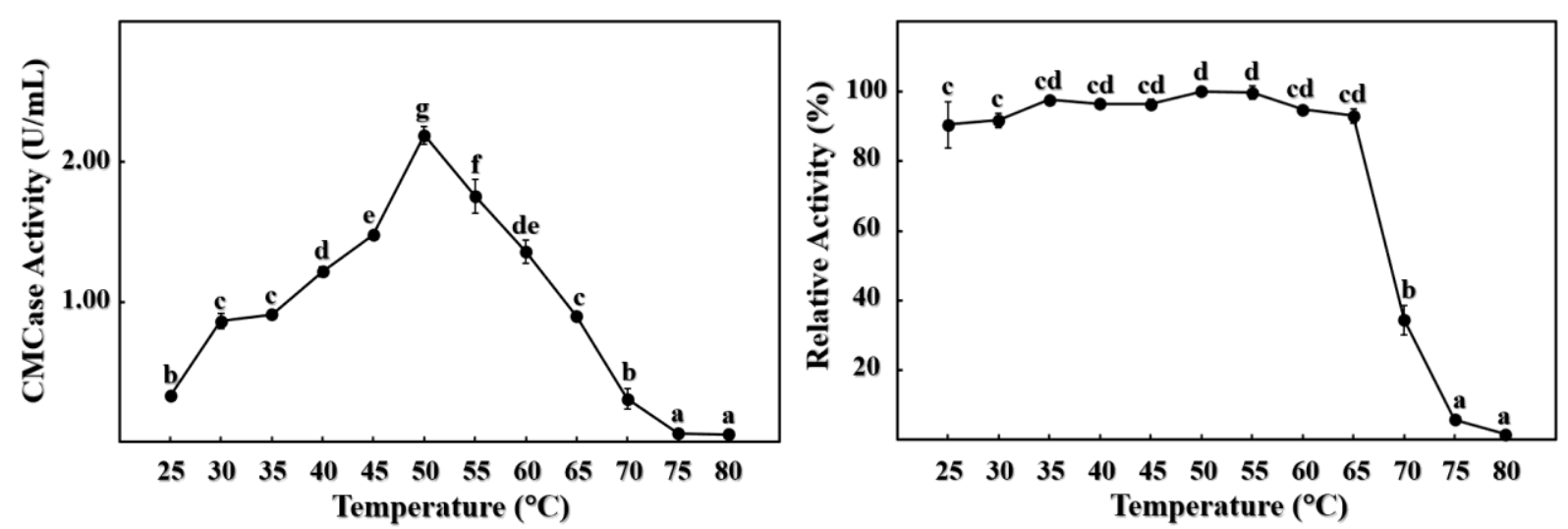

A

\section{B}

Figure 4. (A) The optimum temperature and (B) thermal stability of CMCase activity from crude cellulases of $B$. cereus strain TWV503. Error bars represent the standard deviation of the triplicates. The mean values followed by the same letter were not significantly different according to Tukey's test $(p<0.05)$ among the CMCase activity

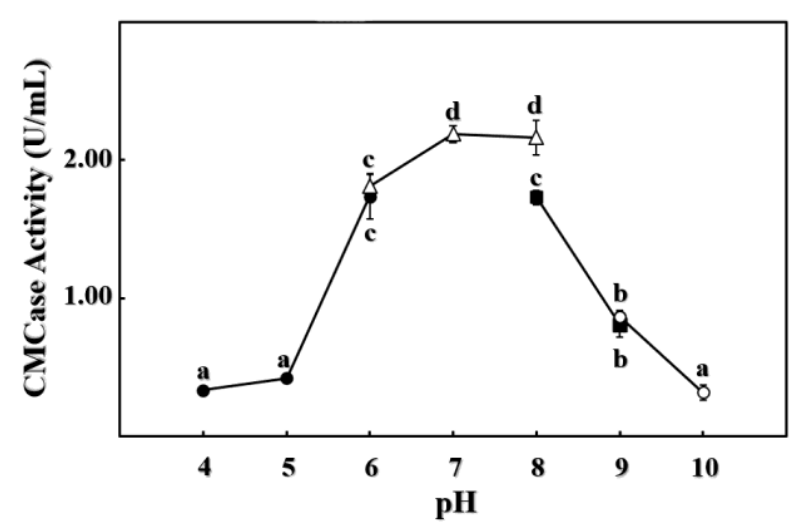

A

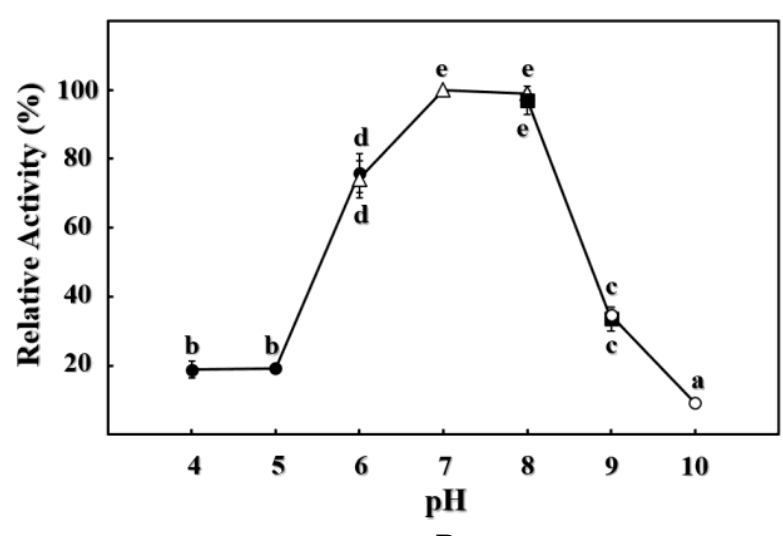

B

Figure 5. (A) The optimum $\mathrm{pH}$ and (B) the $\mathrm{pH}$ stability of CMCase activity from crude cellulases of $B$. cereus strain TWV503. CMCase activity was assayed in a citrate buffer $(\bullet)$, sodium phosphate buffer $(\triangle)$, Tris-HCl buffer $(\square)$, and glycine-NaOH buffer $(\bigcirc)$. Error bars represent the standard deviation of the triplicates. The mean values followed by the same letter were not significantly different according to Tukey's test $(p<0.05)$ among the CMCase activity

Bacillus cereus were the predominant cellulolytic bacteria found in the gut of Odontotermes termites. In this study, they were isolated from termites at all sampling sites. A previous study on the microbial community in the gut of $O$. formosanus termite collected from Taiwan reported that the predominant bacteria isolated by the culture-dependent method belonged to the genus Bacillus of the Phylum Firmicutes (Mathew et al. 2012). A report on the cellulolytic bacteria isolated from the gut of Odontotermes termites collected from India showed that $B$. cereus was the dominant cellulase producer (Sreena et al. 2015). In this study, B. cereus strain TWV503 was considered as the most effective bacterium based on the $\mathrm{HC}$ value obtained from the $\mathrm{CMC}$ agar method. It could produce the crude cellulases with satisfactory performance of endoglucanase (CMCase) activity but barely in total cellulase (FPase) activity. The crude cellulases showed the optimum CMCase activity at a moderate temperature of $50^{\circ} \mathrm{C}$ and stability at up to $70^{\circ} \mathrm{C}$. In addition, its optimum $\mathrm{pH}$ and $\mathrm{pH}$ stability remained in neutral conditions. This differed from the characteristics of B. cereus strain $\mathrm{ODO} 2$ isolated from the gut of Odontotermes termites, which showed optimum activity at the average human body temperature (Sreena et al. 2015). The CMCase activity of B. cereus strain TWV503 was related to other Bacillus cellulases isolated from different environments (Sadhu and Maiti 2013; Chantarasiri 2015). Bacillus species commonly lack significant exoglucanase activity (Wu et al. 2018).

Paenibacillus polymyxa was a cellulolytic bacterium isolated and identified from the gut of termite collected from Prachin Buri Province. It is an endospore-forming bacterium that could colonize a wide range of environments (Padda et al. 2017). A recent study found that $P$. polymyxa was isolated from the gut of a higher termite $(O$. hainanensis) and was identified as a potential cellulase and hemicellulase producer (Pasari et al. 2019). A cellulolytic bacterium isolated from termite gut in Rayong Province was designated as A. baumannii. It is a strictly aerobic and non-motile bacterium that is reported as an opportunistic pathogen in immunocompromised individuals 
(Howard et al. 2012). A. baumannii is one of the culturable cellulolytic bacteria with high activities of cellulases (Karthika et al. 2020). A previous study evidenced that Acinetobacter species could be isolated from some higher termites such as Microcerotermes termites (Pourramezan et al. 2012). Citrobacter sp. and C. farmeri were isolated and identified from the termites in the provinces of Rayong and Chachoengsao. The genus Citrobacter is a group of aerobic bacteria which widely distributed in the water, soil, food, and intestinal tracts of animals (Metri et al. 2013). Citrobacter species are the common symbionts of termite gut that may play an important role in nitrogen metabolism (Muwawa et al. 2016). Some species of Citrobacter have been isolated from the higher termites and exhibited cellulolytic activities (Kavitha et al. 2014). Moreover, Citrobacter species were responsible for lignocellulolytic and hemicellulolytic digestion, which have been isolated from various insects (Handique et al. 2017). The last $S$. marcescens cellulolytic bacterium was isolated from the termite gut in Rayong Province. It is a human opportunistic pathogen that naturally resides in the soil and water, producing a red pigment at room temperature (Ferreira et al. 2020). It was also reported as a cellulolytic bacterium isolated from a higher termite $O$. formosanus (Kavitha et al. 2014). However, a very recent study revealed that this bacterium had insecticidal properties on a higher termite $O$. formosanus by penetrating the insect body and destroying its digestive tract (Fu et al. 2021).

In conclusion, the gut of a higher termite, Odontotermes sp., is a potential source for the isolation of cellulolytic bacteria. There were 5 genera of cellulolytic bacteria isolated from the gut of Odontotermes termites in eastern Thailand based on the RFLP-PCR of $16 \mathrm{~S}$ rRNA gene comprising Acinetobacter, Bacillus, Citrobacter, Paenibacillus, and Serratia. Cellulolytic B. cereus were the predominant bacteria found in the gut of the collected termites. It was revealed that B. cereus strain TWV503 was the most active CMCase bacterium. The prominent characteristic of its CMCase was stability under high temperature and neutral $\mathrm{pH}$ conditions. Therefore, $B$. cereus cellulolytic bacterium could be used in some agriculture, food, and compost industries. Further study should be done on molecular genetic engineering and enzyme purification.

\section{ACKNOWLEDGEMENTS}

This research was funded by Faculty of Science, Energy and Environment, King Mongkut's University of Technology North Bangkok. Contract no. SCIEEKMUTNB-64-001.

\section{REFERENCES}

Boontanom P, Chantarasiri A. 2020. Short Communication: diversity of culturable epiphytic bacteria isolated from seagrass (Halodule uninervis) in Thailand and their preliminary antibacterial activity. Biodiversitas 21: 2907-2913. DOI: 10.13057/biodiv/d210706.
Brune A. 2014. Symbiotic digestion of lignocellulose in termite guts. Nat Rev Microbiol 12: 168-180. DOI: 10.1038/nrmicro3182.

Chantarasiri A. 2014. Novel halotolerant cellulolytic Bacillus methylotrophicus RYC01101 isolated from ruminant feces in Thailand and its application for bioethanol production. KMUTNB Int J Appl Sci Technol 7: 63-68. DOI: 10.14416/j.ijast.2014.07.001.

Chantarasiri A. 2015. Aquatic Bacillus cereus JD0404 isolated from the muddy sediments of mangrove swamps in Thailand and characterization of its cellulolytic activity. Egypt J Aquat Res 41: 257-264. DOI: 10.1016/j.ejar.2015.08.003.

Chantarasiri A. 2020. Diversity of cellulolytic bacteria isolated from a freshwater wetland reserve in Thailand and their cellulolytic activity. Appl Ecol Environ Res 18: 5965-5983. DOI: 10.15666/aeer/1804_59655983.

Chantarasiri A, Boontanom P, Yensaysuk N, Ajwichai P. 2015. Isolation and identification of a cellulase-producing Bacillus sp. strain BR0302 from Thai coastal wetland soil. KMUTNB Int J Appl Sci Technol 8: 197-203. DOI: 10.14416/j.ijast.2015.07.002.

Chiu CI, Yeh HT, Li PL, Kuo CY, Tsai MJ, Li HF. 2018. Foraging phenology of the fungus-growing termite Odontotermes formosanus (Blattodea: Termitidae). Environ Entomol 47: 1509-1516. DOI: 10.1093/ee/nvy140.

Ferbiyanto A, Rusmana I, Raffiudin R. 2015. Characterization and identification of cellulolytic bacteria from gut of worker Macrotermes gilvus. Hayati J Biosci 22: 197-200. DOI: 10.1016/j.hjb.2015.07.001.

Ferreira RL, Rezende GS, Damas MSF, Oliveira-Silva M, Pitondo-Silva A, Brito MCA, Leonardecz E, de Góes FR, Campanini EB, Malavazi I, da Cunha AF, da Silva Pranchevicius MC. 2020. Characterization of KPC-producing Serratia marcescens in an intensive care unit of a Brazilian tertiary hospital. Front Microbiol 11: 956. DOI: 10.3389/fmicb.2020.00956.

Fu R, Zhou L, Feng K, Lu X, Luo J, Tang F. Effects of Serratia marcescens (SM1) and its interaction with common biocontrol agents on the termite, Odontotermes formosanus (Shiraki). J For Res 32: 1263-1267. DOI: 10.1007/s11676-020-01122-w.

Handique G, Phukan A, Bhattacharyya B, Baruah AALH, Rahman SW, Baruah R. 2017. Characterization of cellulose-degrading bacteria from the larval gut of the white grub beetle Lepidiota mansueta (Coleoptera: Scarabaeidae). Arch Insect Biochem Physiol 94: e21370. DOI: $10.1002 /$ arch.21370.

Hongoh Y. 2011. Toward the functional analysis of uncultivable, symbiotic microorganisms in the termite gut. Cell Mol Life Sci 68: 1311-1325. DOI: 10.1007/s00018-011-0648-z.

Howard A, O’Donoghue M, Feeney A, Sleator RD. 2012. Acinetobacter baumannii an emerging opportunistic pathogen. Virulence 3: 243250. DOI: $10.4161 /$ viru. 19700 .

Juturu V, Wu JC. 2014. Microbial cellulases: engineering, production and applications. Renew Sustain Energy Rev 33: 188-203. DOI: 10.1016/j.rser.2014.01.077.

Karthika A, Seenivasagan R, Kasimani R, Babalola OO, Vasanthy M. 2020. Cellulolytic bacteria isolation, screening and optimization of enzyme production from vermicompost of paper cup waste. Waste Manage 116: 58-65. DOI: 10.1016/j.wasman.2020.06.036.

Kavitha D, Vijayarani K, Kumanan K. 2014. 16S rRNA typing of cellulolytic bacteria from the termite Odontotermes formosanus. Ind $\mathrm{J}$ Vet Anim Sci Res 43: 359-368.

König H, Li L, Fröhlich J. 2013. The cellulolytic system of the termite gut. Appl Microbiol Biotechnol 97: 7943-7962. DOI: 10.1007/s00253-013-5119-z.

Korb J. 2018. Social evolution in termites. In: Breed MD, Moore J (eds) Encyclopedia of Animal Behavior. Academic Press, Oxford, UK. DOI: 10.1016/B978-0-12-809633-8.20751-6.

Makonde HM, Boga HI, Osiemo Z, Mwirichia R, Mackenzie LM, Göker M, Klenk HP. 2013. 16S-rRNA-based analysis of bacterial diversity in the gut of fungus-cultivating termites (Microtermes and Odontotermes species). Antonie van Leeuwenhoek 104: 869-883. DOI: 10.1007/s10482-013-0001-7.

Manjula A, Pushpanathan M, Sathyavathi S, Gunasekaran P, Rajendhran J. 2016. Comparative analysis of microbial diversity in termite gut and termite nest using ion sequencing. Curr Microbiol 72: 267-275. DOI: $10.1007 / \mathrm{s} 00284-015-0947-y$.

Maurice N, Erdei L. 2018. Termite gut microbiome. In: Khan M, Ahmad W (eds) Termites and Sustainable Management. Springer, Cham, Switzerland. DOI: 10.1007/978-3-319-72110-1_4

Mathew GM, Ju YM, Lai CY, Mathew DC, Huang CC. 2012. Microbial community analysis in the termite gut and fungus comb of 
Odontotermes formosanus: the implication of Bacillus as mutualists. FEMS Microbiol Ecol 79: 504-517. DOI: 10.1111/j.15746941.2011.01232.x.

Menendez E, Garcia-Fraile P, Rivas R. 2015. Biotechnological applications of bacterial cellulases. AIMS Bioeng 2: 163-182. DOI 10.3934/bioeng.2015.3.163.

Metri BC, Jyothi P, Peerapur BV. 2013. Antibiotic resistance in Citrobacter spp. isolated from urinary tract infection. Urol Ann 5: 312-313. DOI: 10.4103/0974-7796.120295.

Mikaelyan A, Dietrich C, Köhler T, Poulsen M, Sillam-Dussès D, Brune A. 2015. Diet is the primary determinant of bacterial community structure in the guts of higher termites. Mol Ecol 24: 5284-5295. DOI: $10.1111 / \mathrm{mec} .13376$.

Muwawa EM, Budambula NLM, Osiemo ZL, Boga HI, Makonde HM. 2016. Isolation and characterization of some gut microbial symbionts from fungus-cultivating termites (Macrotermes and Odontotermes spp.). Afr J Microbiol Res 10: 994-1004. DOI: 10.5897/AJMR2016.8060.

Nimchua T, Thongaram T, Uengwetwanit T, Pongpattanakitshote S, Eurwilaichitr L. 2012. Metagenomic analysis of novel lignocellulosedegrading enzymes from higher termite guts inhabiting microbes. J Microbiol Biotechnol 22: 462-469. DOI: 10.4014/jmb.1108.08037.

Obeng EM, Adam SNN, Budiman C, Ongkudon CM, Maas R, Jose J. 2017. Lignocellulases: a review of emerging and developing enzymes, systems, and practices. Bioresour Bioprocess 4: 16. DOI: 10.1186/s40643-017-0146-8.

Otani S, Mikaelyan A, Nobre T, Hansen LH, Koné NA, Sørensen SJ, Aanen DK, Boomsma JJ, Brune A, Poulsen M. 2014. Identifying the core microbial community in the gut of fungus-growing termites. Mol Ecol 23: 4631-4644. DOI: 10.1111/mec.12874.

Padda KP, Puri A, Chanway CP. 2017. Paenibacillus polymyxa: a prominent biofertilizer and biocontrol agent for sustainable agriculture. In: Meena VS, Mishra P, Bisht J, Pattanayak A (eds) Agriculturally Important Microbes for Sustainable Agriculture. Springer, Singapore. DOI: 10.1007/978-981-10-5343-6 6.

Pasari N, Gupta M, Eqbal D, Yazdani SS. 2019. Genome analysis of Paenibacillus polymyxa A18 gives insights into the features associated with its adaptation to the termite gut environment. Sci Rep 9: 6091. DOI: 10.1038/s41598-019-42572-5.
Peterson BF, Scharf ME. 2016. Lower termite associations with microbes: synergy, protection, and interplay. Front Microbiol 7: 422. DOI: $10.3389 /$ fmicb. 2016.00422 .

Pourramezan Z, Ghezelbash GR, Romani B, Ziaei S, Hedayatkhah A. 2012. Screening and identification of newly isolated cellulosedegrading bacteria from the gut of xylophagous termite Microcerotermes diversus (Silvestri). Microbiol 81: 736-742. DOI: $10.1134 / \mathrm{S} 0026261712060124$.

R Core Team. 2020. R: A Language and environment for statistical computing. R Core Team, Vienna, Austria.

Sadhu S, Maiti TK. 2013. Cellulase production by bacteria: a review. $\mathrm{Br}$ Microbiol Res J 3: 235-258. DOI: 10.9734/BMRJ/2013/2367.

Sharma D, Joshi B, Bhatt MR, Joshi J, Malla R, Bhattarai T, Sreerama L. 2015. Isolation of cellulolytic organisms from the gut contents of termites native to Nepal and their utility in saccharification and fermentation of lignocellulosic biomass. J Biomass Biofuel 2: 23685964. DOI: 10.11159/jbb.2015.002.

Shweta A. 2014. Cellulases of bacterial origin and their applications: a review. Int J Sci Res 3: 1652-1655.

Sreena CP, Resna NK, Sebastian D. 2015. Isolation and characterization of cellulase-producing bacteria from the gut of termites (Odontotermes and Heterotermes species). Br Biotechnol J 9: 1-10. DOI: $10.9734 / \mathrm{BBJ} / 2015 / 20001$

Taechapoempol K, Sreethawong T, Rangsunvigit P, Namprohm W, Thamprajamchit B, Rengpipat S, Chavadej S. 2011. Cellulaseproducing bacteria from Thai higher termites, Microcerotermes sp.: enzymatic activities and ionic liquid tolerance. Appl Biochem Biotechnol 164: 204-219. DOI: 10.1007/s12010-010-9128-4.

Wititsiri S. 2011. Production of wood vinegars from coconut shells and additional materials for control of termite workers, Odontotermes sp. and striped mealy bugs, Ferrisia virgata. Songklanakarin J Sci Technol 33: 349-354.

Wu B, Zheng S, Pedroso MM, Guddat LW, Chang S, He B, Schenk G. 2018. Processivity and enzymatic mechanism of a multifunctional family 5 endoglucanases from Bacillus subtilis BS-5 with potential applications in the saccharification of cellulosic substrates. Biotechnol Biofuels 11: 20. DOI: 10.1186/s13068-018-1022-2. 